\title{
Effects of oil prices on net private saving gap: 2001 crisis in Turkey
}

\author{
Ahmet Sengonul $^{1 \star}$ and Suleyman Degirmen ${ }^{2,3}$ \\ ${ }^{1}$ Department of Economics, Cumhuriyet University Campus, 58140, Sivas/Turkey. \\ ${ }^{2}$ Department of Economics, Mersin University Ciftlik Koy Campus 33342 Mersin/Turkey. \\ ${ }^{3}$ Department of Economics, Hamburg University VMP 5 Room \# 3111, 20146, Hamburg/Germany.
}

Accepted 8 September, 2010

\begin{abstract}
After the liberalization of capital account in 1989 in Turkey, speculative capital inflows have significantly come for the higher interest rates induced by incremental budget deficits in Turkey. While the budget standing has got closer to balance, current account deficit problem has kept its agenda. Thus, a new potential determinant of current account, namely the gap between private savings and investment is proposed recently. Therefore, the study explores the determinants of net private savings and investment gap along with the effect of oil price shocks on them before and after the 2001 crisis. The reason of introducing the oil price as an additional variable to the model is to explain the effect of oil prices on current account deficit through the private savings and investment gap. For this purpose, the bound testing approach to cointegration within an autoregressive distributed lag (ARDL) framework and error-correction model (ECM) methodology, is applied for the period of 1990: Q1-2007:Q3. Expected empirical results provide evidence of the simultaneous effectiveness of interest rate for deposit, GDP growth, and oil price on net private savings rate in both short and long runs.
\end{abstract}

Key words: Oil prices, savings - investment gap, autoregressive distributed lag (ARDL).

\section{INTRODUCTION}

Neo-liberal approach dominated on economic policies since 1980s is based on the assumption that when developing countries lacking funds accomplish financial liberalization they can easily benefit from foreign funds (Ostry and Reinhart, 1995:16). In recent years, there has been extensive empirical research on the relationship between savings, investment and economic growth. Taking the importance of fluctuations in oil prices for both developed and developing economies into account, researchers are motivated and masse by increasing concern over the falling saving rates in the major OECD countries, the growing divergence in saving and investment rates among the developing countries, and the increasing emphasis of the indispensable role of investment in economic growth issues. Foreign capital inflows are also receiving attention because of their potential to finance investment and promote economic growth, although, they can be problematic for developing

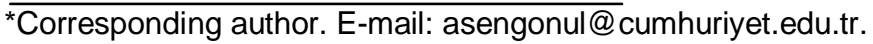

countries such as Turkey (Verma and Wilson, 2005:1).

Embedded in interest rate increases, exchange rate depreciations, chronic large budget deficits and current account deficits Turkey has recently experienced a series of macroeconomic shocks. Beginning with the liberalization of capital account in the 1989, speculative short-term foreign capital inflows have significantly increased due to the rise in interest rates rendering from the growth in budget deficits. Turkey has also experienced current account deficits for many years. The Keynesian twin-deficits argument raised within the framework of Mundell-Fleming model, and the Ricardian equivalence hypothesis offer an alternative explanation to the twin-deficits phenomenon. Twin-deficit (even triple deficits) issue has been treated under several heads without considering the determinants of savings and investment along with current account deficit. In a recent study for Turkey, Sengonul (2008) provides evidence on the twin deficit hypothesis between the current account and private saving deficits in the long run, and budget deficits in the short run, while supporting the triple deficit proposition among the balances at contemporaneous 
period. As a potential long run determinant of current account deficit, this paper brings further research on explanation of private savings-investment gap by focusing private savings and investment equation and their determinants.

The paper employs the autoregressive distributed lag (ARDL) approach to cointegration to examine determinants of net private saving ratio in light of oil price shocks, for the Turkish economy. Rather than analyzing the determinants of saving and investments individually, it uses different approach to determine what factors ${ }^{1}$ would affect the net private saving gap ${ }^{2}$, which constitutes the significance of our study. After the 1973 and 1979 oil crises, rather than using of its own domestic energy (or oil) resources, Turkey chose to be more dependent on imported energy (or oil).

Kilic and Kaya (2007) and Yilmaz and Uslu (2007) and Demirtas (2001) note this change in Turkey's energy policy after the second half of the 1980's (Erdogdu (Nov. 2007)). Scarcity in domestic oil supply might be the main reason behind this dependency. Advanced addiction on imported oil has affected the Turkish economy in terms of both oil price and quantity, which will be briefly demonstrated here. Starting from the trade and afterwards capital liberalization period, Turkey has been gradually using more imported oil including a slump during crisis. While the share of imported amount percentage has been declining in time, dependency ratio, which is the imported amount of oil to total amount of oil needed, has been increased since 1990.

This means that imported oil amount relatively gets small share in the total import figures but this still is not enough to meet the needs of oil consumption. Thus, we become incrementally dependent upon foreign oil. Thus, the relationship among oil price changes and savinginvestment gap put itself into the agenda, which also give a reference for the picture of current account situation as well. In conclusion, oil price changes always increased private savings rates more than private investment whereas the net private saving gap has declined after 2001 Turkish financial crisis, which supports that the magnitude of two effects may differ before and after the crisis.

\section{THE RELATIONSHIP BETWEEN THE DEFICITS}

Theoretical model is constructed on a simple Keynesian open macroeconomic model as seen in the following derived version ${ }^{3}$.

$Y=C+I+G+(-M-$

\footnotetext{
${ }^{1}$ Potential factors are oil price, income and wealth, and interest rates.

2 Net private savings and investment gap term is used to express just the difference between gross savings and investment.

3 It is acknowledged from S. Schmitt-Grohe and Martin Uribe, (2008), International Macroeconomics, Draft Version, Chapters 1 and 5.
}

$T B=(X-M)($ Trade balance $)$

$T B=(X-M)=Q-C-G-I \quad(\mathrm{Q}$ is $\mathrm{GDP})$

Plugging this into current account, $C A=r B+T B$ yields $C A=r B+Q-C-G-I$, (rB is net investment income).

The sum of GDP and net investment income, is called national income, $\mathrm{Y}$ or gross national product, GNP.

$Y=Q+r B$ and $\mathrm{B}=0 .{ }^{4}$

Combining the last two expressions,

$C A=Y-C-G-I$

National savings, $\mathrm{S}$, is the difference between income, consumption and government expenditure.

$S=Y-C-G$

It then follows from Equation (4) that the current account is:

$C A=S-I$

Thus, (CA) can be re-written that $\boldsymbol{S}^{P}-I^{P}$, comprises the private saving-investment balance and $\boldsymbol{S}^{G}-I^{G}$, is public saving-investment balance in Equation (6).

$C A=\boldsymbol{C}^{P}-I^{P} \pm \mathbf{1}^{G}-I^{G}$

Private savings in period t, $S_{t}^{P}$, positively depends on real gross national disposable income, $G N D I_{t}$, and real interest rate on deposits (savings), $R D R_{t}$, while negatively depends on oil prices, OIL $_{t}$. GNDI is calculated by subtracting taxes, $T X_{t}$, and adding transfers, $T R_{t}$, to the real income, $Y_{t}$. This is $G N D I_{t}=Y_{t}-T X_{t}+T R_{t}$. Therefore, $S_{t}^{P}$ turns to;

$S_{t}^{P}=c+s_{1} \mathrm{GNDI}_{t}+s_{2} \mathrm{OIL}_{t}+s_{3} R D R_{t}$

Private investment spending in period $\mathrm{t}, I_{t}^{P}$, positively depends on realGDP, that is., $Y_{t}$, and negatively depends on real prime lending rate, $L R_{t}$, and oil prices, $O I L_{t}$, as given in Equation (5).

\footnotetext{
4 Since current accounts' largest component is trade balance, the identity defines the trade balance as current account balance by assuming investment income and transfers in the current account balance are trivial or zero. In this case GDP can also be used interchangeably with GNP.
} 
$I_{t}^{P}=a+i_{1} Y_{t}+i_{2} O I L_{t}+i_{3} L R_{t}$
Subtracting the Equation (5) from the Equation (4) to reach the Equation (6) yield;

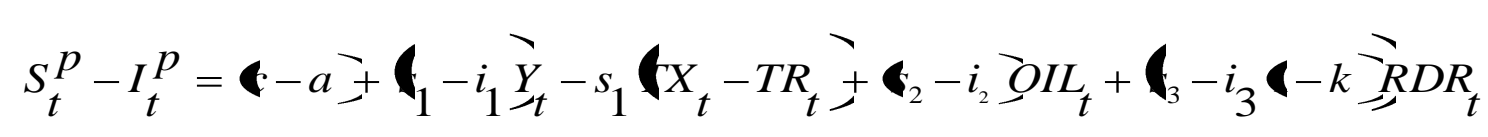

Banks determines the real prime lending rate, $L R_{t}$ by adding up a sort of mark-up rate, $\left(1+k_{t}\right)$, to the deposit rate $R D R_{t} \quad$ that is $\left(L R_{t}=R D R_{t}\left(+k_{-}^{-5}\right)\right.$. The econometric model to be tested is the net private saving rate equation:

$$
\begin{aligned}
& N P S R_{t}=\left(S_{t}^{P}-I_{t}^{P}\right) / G D P_{t} . \\
& N P S R_{t}=\alpha+\beta_{1} Y_{t}+\beta_{2} \text { OIL }_{t}+\beta_{3} R D R_{t}+\beta_{4} N T R_{t}+u_{t}
\end{aligned}
$$

$\alpha=\boldsymbol{C}-a^{-}$is the constant term representing the difference between the autonomous private savings and private investment. $\beta_{1}=\boldsymbol{C}_{1}-i_{1}$, is the difference between the sensitivity (or elasticity) of private savings to disposable income and the sensitivity of private investment to real income. If it is positive, income is more pronounced for private saving rather than for investment. $\beta_{2}=\boldsymbol{C}_{2}-i_{2}$ is the relative sensitivity of private savings and investment to oil price changes. $B_{2}>0$ indicates the private savings is more sensitive to oil price changes than private investment is, or vice versa. If the coefficient is zero the effect of oil price changes on both private savings and investment are considered same. $\beta_{3}=\zeta_{3}-i_{3}(-k)$ is the difference between interest rate sensitivity to savings and the product of interest rate sensitivity of investment and (1- markup rate) ${ }^{6} . \beta_{4}=s_{1}$ is the sensitivity of net private savings to net tax ratio, $N T R_{t}=\left(X_{t}-T R_{t} \backslash G D P_{t}\right.$ which is also the sensitivity of private savings to disposable income in Equation 10.

\section{DATA AND EMPIRICAL STUDY}

Adapting an empirical analysis of the paper, this paper attempts to explore the determinants of private savings-investment in which oil

\footnotetext{
${ }^{5}$ This kind of connection between the lending and deposits rate is required to emphasize the fact that lending rates follows deposits rates with some distance, and the necessity of describing the lending rates in terms of deposit rates is born because of unavailability of the Turkish lending rates data.

${ }^{6}$ In order to interpret $\beta_{3}$ coefficient, consider two extreme cases: (i) If mark up rate is $100 \%$ (i.e., $k=1$ ) net private saving rate will be determined only by sensitivity of savings to deposit rate $S_{3}$, which is equal to $\beta_{3}$. (ii) If mark up rate is $0 \%$ (i.e., $k=0$ ) net private saving rate will be determined by difference between the sensitivity of savings to deposit rate $s_{3}$ and the sensitivity of investment to lending rate $i_{3}, \beta_{3}=\left(s_{3}-i_{3}\right)$, which is empirical question. In general, as $k$ (mark up rate) increases, net private saving rate will be dominantly determined by sensitivity of savings to deposit rate, $s_{3}$ : Therefore, the volume of savings held by banks in deposit accounts will not lend to investors which finally yield net private saving turning to positive.
}

price is included as an alternative variable, given by Equation 10 . Accordingly, the long term effects of these determinants along with oil price shocks to net private savings before and after the 2000 2001 Turkish financial crisis will be tested for 1990:Q1-2007:Q3. NPRS and NTR are scaled with GDP, and all series are seasonally adjusted. Real deposit rate is calculated by deflating the 3-month nominal deposit rate with $\mathrm{CPI}$.

The data used in this study is collected on quarterly basis from the Central Bank of Republic of Turkey electronic data delivery system (EVDS) (http://tcmbf40.tcmb.gov.tr/cbt.html). The other consolidated balance budget series, like taxes and transfers used in calculating private savings and disposable income, are taken from the Ministry of Finance.

\section{PRELIMINARY TESTS FOR THE ECONOMETRIC MODEL}

For identifying the order of integration and structural changes, augmented Dickey-Fuller (ADF) and Zivot and Andrews tests (ZA), for the existence of unit root and structural breaks in series, are employed and reported in Table 1. The stationary test results show that all series, except RDR for the ADF, RDR and NTR for the ZA test, are integrated of order 1. ZA test results also indicate breaks in both intercept and trend, and adding a dummy variable into the model to account for the effects of 2000 - 2001 crises after 2001:Q1 on NPSR.

When the variables are integrated with mix of either order of $\mathrm{I}(0)$ or I(1), Engle and Granger (1987) and Johansen and Juselius (1990) cointegration tests requiring equal order of integration, are not applicable. Alternatively, ARDL bounds testing procedure, which also explores the different optimal lags of each variable in the model for small samples, proposed by Pesaran et al. (2001) can be applied. The bound test procedure for checking the cointegration in Equation 10 is conducted with the ARDL model ${ }^{7}$ following Pesaran et al. (2001):

$$
\begin{aligned}
& \Delta N P S R_{t}=\alpha_{0}+\sum_{i=1}^{p} \beta_{i} \Delta N P S R_{t-i}+\sum_{i=0}^{p} \sigma_{i} \Delta L N G D P_{t-i}+\sum_{i=0}^{p} \rho_{i} \Delta L N O I L_{t-i}+\sum_{i=0}^{p} \gamma_{i} \Delta R D R_{t-i} \\
& \quad+\lambda_{1} N P S R_{t-1}+\lambda_{2} L_{N G D P_{t-1}}+\lambda_{3} \text { OIL }_{t-1}+\lambda_{4} R D R_{t-1}+u_{t}
\end{aligned}
$$

where $\Delta$ is the first difference operator and $p$ is the optimal lag length. The coefficients of $\alpha, \beta, \sigma, \rho$, and $\gamma$ are the parameters that show the short run, whereas the $\square$ s show the long run dynamics of the model. The null hypothesis, $\lambda_{1}=\lambda_{2}=\lambda_{3}=\lambda_{4}=0$ indicates there is no cointegration among the variables. Table 2 shows the F-statistic of cointegration relationships, the Akaike's (AIC) and Schwarz's Bayesian (SBC)

\footnotetext{
${ }^{7}$ A deterministic trend and intercept are also added in to the model. During computing the regressions, the lagged changes of the net tax ratio variable $\Delta N T R_{t-1}, \Delta N T R_{t-2}, \ldots . ., \Delta N T R_{t-8}$ and deterministic trend variable were insignificant in most regressions. Following to Pesaran (2001:310), these variables are excluded from the model for the sake of parsimony and to avoid unnecessary over-parameterization.
} 
Table 1. Unit root tests.

\begin{tabular}{|c|c|c|c|c|c|c|}
\hline \multirow[t]{2}{*}{ Variables } & \multicolumn{3}{|c|}{ ADF test statistics(with intercept and trend) } & \multicolumn{3}{|c|}{ ZA test statistics(with intercept and trend) } \\
\hline & Level & First Dif. & Integration & t-value & t-critical & Integration \\
\hline NPSR & $-3.67(0.03)^{\star *}$ & $-5.67(0.00)^{\star * \star}$ & I (1) & $-4.96^{\mathrm{a}}$ & -4.82 & $I(1)$ \\
\hline LNGDP & $-2.55(0.30)$ & $-10.41(0.00)^{\star * *}$ & I (1) & $-4.48^{\text {aaa }}$ & -5.57 & $I(1)$ \\
\hline LNOIL & $-1.72(0.72)$ & $-7.46(0.00)^{\star * *}$ & I (1) & $-4.83^{\text {aaa }}$ & -5.57 & I (1) \\
\hline RDR & $-6.37(0.00)^{\star * *}$ & $-7.95(0.00)^{\star \star *}$ & I (0) & $-7.24^{\text {aaa }}$ & -5.57 & I (0) \\
\hline NTR & $-3.66(0.03)^{* *}$ & $-10.58(0.00)^{* * *}$ & I (1) & $-6.17^{\text {aаa }}$ & -5.57 & $\mathrm{I}(0)$ \\
\hline
\end{tabular}

${ }^{* * *},{ }^{* *}$, and * shows the p-values at the 1, 5 and $10 \%$ significant levels, respectively. ${ }^{\text {aaa }}$, aa ${ }^{\text {, and, }}{ }^{a}$ shows the $\mathrm{t}$-values at the 1,5 and $10 \%$ significant levels, respectively, according to the t-critical values $(-5.57,-5.08$ and -4.82$)$ which are taken from Zivot and Andrews (1992) for the model $\mathrm{C}$, which allows both breaks in intercept and trend. If the estimated t-value reported in this Table is lower than the t-critical value given in Zivot and Andrews (1992:254), the null hypothesis that there is a unit root for the relevant variable is rejected.

information criteria with no residual serial correlation against order 1 and 4 , as indicated in Pesaran et al. (2001, p.311). In determining the optimum lag length $(p)$, the Equation 11 is estimated by least squares from $p=1$ to $p=8 .^{8}$

According to results, optimal lag order selected by AIC and SBC are 6 and 1 , with the minimum values of -3.2925 and -2.4751 . The F-statistics for the cointegration test, corresponding to the selected order of lags are 3.9720 and 4.2342 . $^{9}$ The calculated F- statistics selected by AIC and SBC are higher than the upper bound critical value (3.52) and (4.01) at the 0.10 and 0.05 significant levels respectively. Thus, the null hypothesis of no cointegration can be rejected at the 0.10 and 0.05 levels and indicates that there is a cointegration relationship among the variables.

\section{LONG AND SHORT RUN REGRESSION RESULTS}

Once cointegration or long run relationships of the variables in Equation 11 is established, ARDL model testing procedure continues with estimating the long run ARDL model given in Equation 12. The model adds two dummy variables into the model to account for the effects of 2001. The first dummy, DUM1, is added according to the structural break in NPSR suggested by the ZA test and represents the period after the Turkish financial crises. The second dummy, DUMLNOIL, in the interactive or multiplicative form, which is the product of natural logarithm of oil price and the value of 1 during and after the periods of 2001:Q1, to capture how much differentiation in the effect of oil price changes occurred between the periods of before and after the 2001 Turkish financial crisis. Accordingly, the coefficient of LNOIL measures only the effect of oil price changes on NPRS before the mentioned crisis period.

\footnotetext{
${ }^{8}$ Since the study uses the quarterly data, number of maximum lag should have been taken 12 as Enders (1995) suggested. However, maximum lag is set as 8 and cannot be increased further given the relatively few number of observations.

${ }^{9}$ The critical value belongs to the Table CI (iii), Case III: Unrestricted intercept and no trend) in Pesaran et al. (2001:300). The bound test was also replicated for restricted intercept and no trend, however the results were not changed significantly.
}

$$
\begin{aligned}
& N P S R_{t}=\alpha_{1}+\sum_{i=1}^{p} \lambda_{1} N P S R_{t-i}+\sum_{i=0}^{p_{1}} \lambda_{2} L N G D P_{t-i}+\sum_{i=0}^{p_{2}} \lambda_{3} L_{N O I L_{t-i}}+\sum_{i=0}^{p_{3}} \lambda_{4} R D R_{t-i} \\
& \quad+\eta_{1} D U M 1+\eta_{2} \text { DUMLNOIL }+v_{t}
\end{aligned}
$$

The model is estimated by least squares through selecting the orders of the ARDL $\left(p=0, p_{1}=1, p_{2}=0, p_{3}=5\right)$ model in the five variables according to SBC. ${ }^{10}$ The estimated long run coefficients of the model given in Equation 12 are reported in Table $4 .^{11}$

According to long run statistics of Equation 12, given in the Table 3, real GDP growth has a negative and highly significant impact on NPSR. For a $1 \%$ increase in the real GDP, NPRS, on average, decreases by about $0.39 \%$. This is an evidence that the growth rate in investment created by $1 \%$ increase in real GDP is more by $0.39 \%$ than the growth rate in savings created by $1 \%$ increase in real GDP. As indicated in Table 4, in the short run, however, the impact of GDP growth on NPSR is positive and significant indicating income rises positively affect savings more than investment. The estimated coefficient of RDR is found positive and significant effect on NPSR in both short and long run. In the long run, for a $1 \%$ increase in RDR, the NPSR, on average, increase by about $0.22 \%$. This positive correlation explicitly proves that the growth rate in investment created by $1 \%$ increase in RDR is more by $0.22 \%$ than the growth rate in savings created by $1 \%$ increase in RDR, in the long run. An explanation for the significance of RDR on NPSR could be the temporal inconsistency between the nominal effects of the higher interest rates on the private saving

\footnotetext{
10 The ARDL method searches across the $(p+1)^{k}=8^{4}=4096$ number of regressions to obtain optimal number of lag for each variable, where $p$ is the maximum number of lag ( 8 in this study) and $k$ is the number of variables in the model in Equation (11).

11 The result are obtained from the estimated model selected by the SBC criteria by using maximum lag order of 8 , but not that of AIC since the orders of ARDL $\left(p, p_{1}, p_{2}, p_{3}\right)$ selected by AIC varied significantly depending on given maximum lag, and the results also failed to pass the diagnostic tests particularly serial autocorrelation and normality.
} 
Table 2. Selecting the lag order for the bound test.

\begin{tabular}{clcccc}
\hline \multirow{2}{*}{ Number of lags $(\mathbf{p})$} & \multicolumn{2}{c}{ Model selection criteria } & \multicolumn{2}{c}{ F-statistics } & \multicolumn{2}{c}{ Serial correlation LM test statistics } \\
\cline { 2 - 6 } & AIC & SBC & Value & $\chi_{B G S C}^{2}(1)$ & $\chi_{B G S C}^{2}(4)$ \\
\hline 1 & -2.9284 & -2.4751 & 4.2342 & 0.3785 & 0.3309 \\
2 & -2.9427 & -2.3552 & 5.1140 & 0.0213 & 0.2019 \\
3 & -3.1399 & -2.4159 & 2.7178 & 0.2355 & 0.0268 \\
4 & -3.1274 & -2.2649 & 3.6407 & 0.0959 & 0.063 \\
5 & -3.0344 & -2.0309 & 2.0718 & 0.5729 & 0.1346 \\
6 & -3.2925 & -2.1456 & 3.9720 & 0.1337 & 0.1806 \\
7 & -3.2918 & -1.9991 & 4.7339 & 0.0336 & 0.0030 \\
8 & -3.4206 & -1.9796 & 6.0720 & 0.0011 & 0.0000 \\
\hline
\end{tabular}

$\chi_{B G S C}^{2}$ is the $\mathrm{p}$-values of the Breusch-Godfrey serial correlation LM statistics for testing no residual serial correlation against order 1 and 4 respectively. The symbols *, and ** denote significance at $0.05,0.025$ levels, respectively.

Table 3. Long run model.

\begin{tabular}{lcccc}
\hline Regressor & Coefficient & Standard error & t-ratio & p-value \\
\hline LNGDP & -0.3958 & 0.1573 & -2.5163 & {$[0.015]$} \\
LNOIL & 0.0895 & 0.0380 & 2.3532 & {$[0.023]$} \\
RDR & 0.2283 & 0.0559 & 4.0817 & {$[0.000]$} \\
INTERCEPT & 3.6161 & 1.4828 & 2.4388 & {$[0.018]$} \\
DUM1 & 0.0550 & 0.0167 & 3.2868 & {$[0.002]$} \\
DUMLNOIL & -0.0382 & 0.0113 & -3.3560 & {$[0.002]$} \\
TREND & 0.0056 & 0.0017 & 3.1774 & {$[0.003]$} \\
\hline
\end{tabular}

Table 4. Error correction model of the $\operatorname{ARDL}(0,1,0$ and 5$)$.

\begin{tabular}{|c|c|c|c|c|}
\hline Regressor & Coefficient & Standard error & t-ratio & p-value \\
\hline dLNGDP & 0.3487 & 0.1466 & 2.3783 & {$[0.021]$} \\
\hline $\mathrm{dRDR}$ & 0.2307 & 0.0553 & 4.1649 & {$[0.000]$} \\
\hline dLNOIL & -0.1879 & 0.0531 & -3.5369 & {$[0.001]$} \\
\hline dLNOIL1 & -0.0898 & 0.0592 & -1.5158 & {$[0.136]$} \\
\hline dLNOIL2 & -0.2272 & 0.0547 & -4.1491 & {$[0.000]$} \\
\hline dLNOIL3 & -0.0270 & 0.0533 & -05072 & [0.614] \\
\hline dLNOIL4 & -0.2127 & 0.0477 & -4.4559 & {$[0.000]$} \\
\hline dINTERCEPT & 3.8823 & 1.4430 & 2.6905 & {$[0.010]$} \\
\hline dDUM1 & 0.0550 & 0.0167 & 3.2868 & [0.002] \\
\hline dDUMLNOIL & -0.0382 & 0.0113 & -3.3560 & {$[0.002]$} \\
\hline dTREND & 0.0056 & 0.0017 & 3.1774 & {$[0.003]$} \\
\hline ecm(-1) & -1.0000 & 0.00 & $\mathrm{~N} / \mathrm{A}$ & $\mathrm{N} / \mathrm{A}$ \\
\hline $\begin{array}{l}\bar{R}^{2} \\
F_{S C} \\
\chi_{N O}^{2}\end{array}$ & $\begin{array}{c}\hat{\sigma}=0.0 \\
7334 \\
103.1\end{array}$ & \multicolumn{3}{|c|}{$\begin{array}{l}A I C=103.59, \quad S B C=89.45, \quad D W=1.61 \\
F_{F F}(1,51)=3.47 \text { D.068, } \\
F_{H E T}(1,63)=3.24110 .87^{-}\end{array}$} \\
\hline
\end{tabular}

$\bar{R}^{2}$ is the adjusted squared multiple correlation coefficient, AIC and SBC are Akaike's and Schwarz's Bayesian Information Criteria, $D W$ is the Durbin-Watson statistics, $F_{S C}$ is the $F$ statistics of the Breusch-Godfrey serial correlation LM statistics, $F_{F F}$ is functional form test of the Ramsey's test, $\square$ NORM is normality test based on skewness and kurtosis of residuals, $F_{H E T}$ is the $F$ statistics of White heteroscedasticity test. $\hat{\sigma}$ is the standard error of the regression. p-values are in brackets. 


\section{Plot of Cumulative Sum of Recursive Residuals}

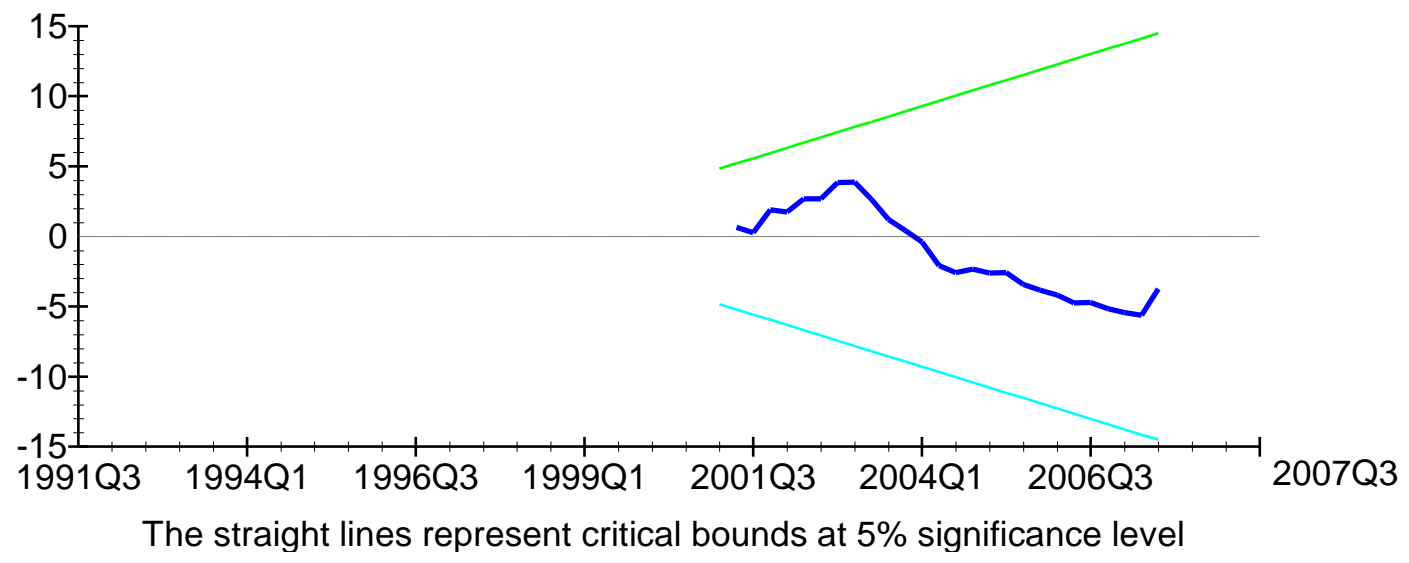

Figure 1. CUSUM.

as well as reel effect on the private investment spending saving.

The main motivation of the study is to determine whether the impact of oil price shocks on NPSR exists and if so, how much differentiation in the effect of oil price changes occurred before and after the 2001 Turkish financial crisis. In order to answer this question, the coefficient of LNOIL and DUMLNOIL should be in interpreted together. The estimated coefficients of LNOIL and DUMLNOIL are significant while the effect of oil price shocks on NPSR has been smaller after the 2001 crisis. Depending on $1 \%$ increase in the price of oil imported, the NPSR, on average, increases by about $0.089 \%$ before the 2001 crisis. This coefficient indicates the sensitivity of savings to price of oil increases is $8.9 \%$ higher than the sensitivity of investment to price of oil increases in the long run. However, the magnitude of this effect has been reduced by the coefficient of DUMLNOIL, 0.038 after the 2001 crisis. Namely, a 1\% increase in the price of oil, the NPSR, on average, increases by $0.051 \%$ after the 2001 crisis. In the short run, the effect of oil price shocks on NPSR is negative; $1 \%$ increase in the oil price, in this case, decreases NPSR at the current, just 2 and 4 periods after the shock, before the 2001 crisis. Contrary to long run results, the magnitude of this effect has risen more negatively, after the 2001 crisis, in the short run. The ECM coefficient suggests an initially cyclical current account movement converges in almost a quarterly period towards the long run equilibrium. ${ }^{12}$ Finally, saving investment gap has reduced by $0.05 \%$ as a response increase in oil price after the 2001 in both short and long run.

\footnotetext{
${ }^{13}$ Pesaran et al. (2001:313) explains the reason of higher coefficient of the (ECM) is due to using the higher lag lengths just like in our model. For the just sake of checking the validity of this reasoning, the ECM coefficients are reestimated by the other criterion like AIC, , and Hannan-Quinn (by shortening the maximum lag length) and the ECM is found smaller, which actually shows an evidence of long run relation within an ARDL resulted with higher order of NPRS, rather than zero.
}

\section{Sensitivity analysis}

Regression for the ARDL equation fits well (0.63) and passes the diagnostic tests, against serial correlation, incorrect functional form, non-normality, and heteroscedasticity at 5\% significant level. Given the disadvantages of the test, because of having low power and missing the important breaks (Pesaran, 2001: 314), cumulative sum (CUSUM) and cumulative sum of squares (CUSUMQ) plots also indicate that the regression coefficients are generally stable over the sample period. As respectively shown in Figures 1 and 2, the plots of both the CUSUM and the CUSUMsq are within the boundaries and confirms the stability of the long run coefficients of variables.

\section{CONCLUSION AND POLICY IMPLICATIONS}

The main contribution of the paper is that the time varying impact of oil price shocks on NPRS is explored. For this reason, as a case study for Turkey, the paper has employed the ARDL approach to cointegration to examine determinants of net private saving ratio in light of oil price shocks and other determinants in the model. Contrary to earlier works, we used different approach to probe into what determine factors would affect the net private saving rather than analyzing the determinants of savings and investment asunder.

The ARDL results indicate that net private saving gap is more explained by a negative relationship with reel gross domestic product, and a positive relationship with real deposit rate, and oil price changes. Negative relationship between net private saving gap and reel GDP is consistent with the Turkish experience, as discussed earlier, with the fact of lower marginal propensity to save in developing countries. The effect of investment on income due to multiplier effect is greater than that of savings, which supports the Keynesian critics on saving 


\section{Plot of Cumulative Sum of Squares of Recursive Residuals}

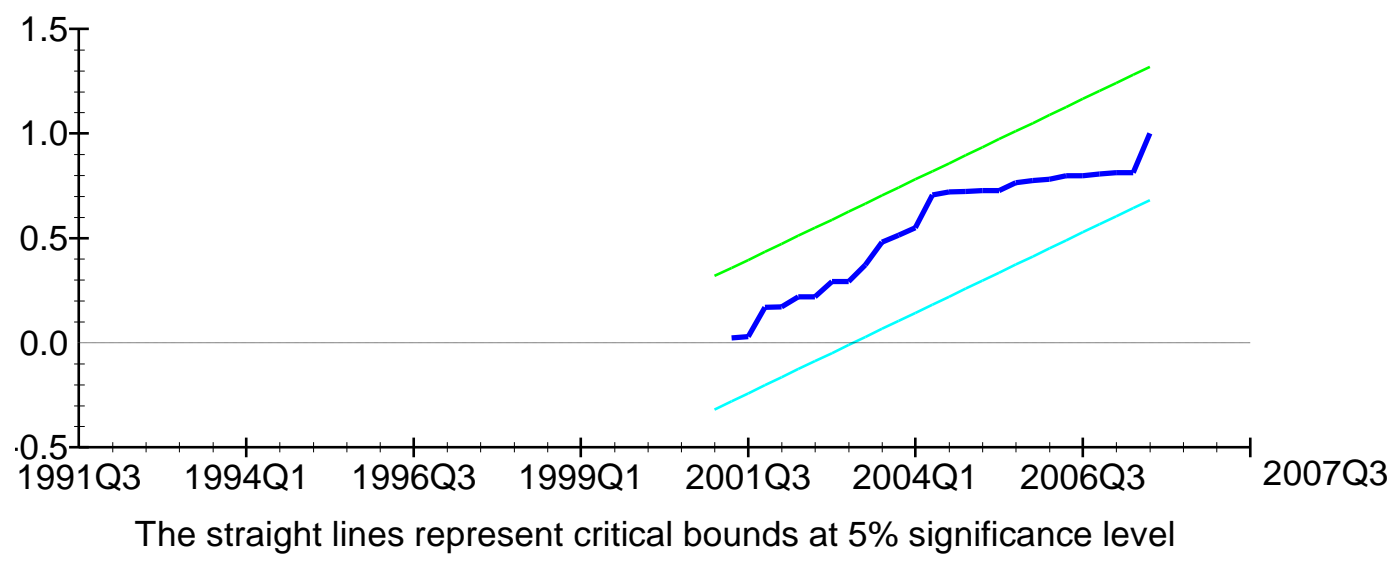

Figure 2. CUSUMsq.

and investment equality. Short run results assert that increase in oil price induces an increase in demand side more than in supply side since saving decreases due to the need of energy in consumption while investment increases due to the need of energy in production. Therefore, increase in oil price has negatively affected NPSR. However, in the long run, the supply side effect is greater than demand side effect. However, the positive effect of oil price changes on NPSR (over supply side effect) has been decreased after the 2001 crisis.

In developing countries, as Turkey, an increase in oil prices in the international market has proved that its decreasing effect on savings was more influential element than that of normal times. Countries who helplessly want to substitute insufficient domestic savings with foreign savings have had to apply policies keeping real interest rate high. Moreover, the effects of rates of return on saving have inconclusive result: first, higher real interest rates on saving raises future expected income and wealth, thus raises current consumption level that is (income effect) and decreases savings. Secondly, higher returns on savings are expected to encourage economic agent to increase savings because postponing the current consumption would imply larger future consumption out of current income that is (substitution effect) (Shiimi and Kadhikawa, 1999:11). If the substitution effect of the rise in interest rates on saving dominates the income effect, saving could increase and vice versa. Fry $(1978,1980)$ suggests that higher real interest rates have positive effects on saving. However, Giovannini $(1983,1985)$ found the effects of real interest rates on saving to be negligible (Shiimi and Kadhikawa, 1999:11). These studies analyzing developing countries case do not provide clarity on determinants of saving. ${ }^{13}$

\footnotetext{
${ }^{13}$ For industrial countries, Koskela and Viren (1982) observed that savings increase as real rates of interest increase. In fact, Balassa (1992) argued that the
}

Nasir and Khalid (2004) also found that saving behavior in Pakistan was insensitive to the interest rate (p.678). ${ }^{14}$

In conclusion regarding this relationship, oil price changes always increased private savings rates more than private investment whereas the net private saving gap has declined after 2001 Turkish financial crisis, which supports that the magnitude of these two effects may differ before and after the crisis. This differentiation before and after the crisis may have also potentially been due to the structural changes such as higher interest rates, excess amount of short-term capital inflows and necessity of using this kind finance for investors and economic growth. Our findings would guide us for a potential research to analyze the similar scenario for the post-2008 global crisis in developed and developing countries.

Following up the test results, we can kindly enable some policy suggestions for servicing the aim of the paper. In oil depended or importing countries, any increase in oil prices cause an incremental decline in saving-investment gap especially after the crisis period, which has been emprically proven. Transmission channels of supply and demand shock effect ends up with the reduction of consumption (induced by the demand side shock effect) and the real output (induced by supply side shock effect) as well (Tang et al., 2009, p.6-7). When we follow the procedure of the transmission channels of the shocks, consumers are forced to decrease their consumed amount of goods and services due to less purchasing power of their real income, there is a probability of choosing more savings now to increase

effect of real interest rates on savings is positive for developing countries (see Ozcan, Gunay and Ertac,(2003:1413).

${ }^{14}$ Insignificance of interest rate can be explained by as business is made after cost and benefit analyses, it might be the case that increasing interest rates are matched with parallel increase in returns therefore making it insignificant. Thirdly it could suggest some estimation methodology problems as well. Largely investment is insignificant to interest rate for the case of Pakistan. 
their consumption in the future. Supply shock effect has similar logic that oil price shock increases cost of production and amount of goods produced decreases and investment decreases as well.

Since the effect of interest rate on NPSR both in long run and short run is inconclusive (or there is no time varying effect of RDR on NPSR), interest rate initially is the only responsible variable to explain the deviations in the long run trend of NPSR. In this sense, interest rate policy (that is monetary policy) applied by central bank has an effect on NPSR; however, it does not create any fluctuations in both short run and long run. Needly keeping real interest rate high is a policy for developing countries to finance their economic growth by substituting foreign savings with domestic ones so that this policy does not help for remedying net domestic savings.

On the other hand, changes in oil price has time varying effects on NPSR. A policy leading an increase in net private savings in oil depended countries could be that while oil price changes on demand side effect should diminish, oil price changes on supply side effect should surge. In other words, oil must be mostly used for production, not for consumption. Moreover, this situaiton has been worsen in countries who have more offen crises. Therefore, incumbent governments in developing countries must use policies diminishing dependency of oil in consumption and in production.

\section{REFERENCES}

Engle RF, Granger CWJ (1987). Cointegration and error correction: representation, estimation and testing, Econometrica, 55: 251-276.

Erdogdu OS (2007). The effects of energy imports: The case of Turkey. Munich Personal RePec Archive, MPRA Paper No.5413). Nov. 2007. Access from: <http://mpra.ub.uni-muenchen.de/5413>.

Ostry DJ, Reinhart CM (1995). Saving and real interest rate in developing countries. Financ. Dev., 32 (4):16-18.

Pesaran MH, Shin Y, Smith RJ (2001). Bounds testing approaches to the analysis of level relationships, J. Appl. Econ., 16: 289-326.

Schmitt-Grohe S, Uribe M (2008). International Macroeconomics, Duke University. Access

from:<http://econ.duke.edu/ uribe/econ170/notes.pdf>(November 2007)

Sengonul A (2008). Different twin deficits in different time intervals: Evidence from Turkey. Asian-Afr. J. Econ. Econ., 8(2): 139-152.

Tang W, Wu L, Zhang ZX (2007). Oil Price shocks and their short- and long-term effects on the Chinese economy. (Munich Personal RePec Archive,

MPRA Paper No.5413). Available at http://mpra.ub.unimuenchen.de/14703 (accessed Nov. 2007).

Verma R, Wilson EJ (2005). Savings, investment, foreign inflows and economics growth of the Indian economy 1950-2001. University of Wollongong Economics Working Paper Series, No. WP 05-23.

Zivot E, Andrews DWK (1992). Further Evidence on the great crash the oil price shock and the unit-root hypothesis. J. Bus. Econ. Stat., 10: 251-270. 